AperTO - Archivio Istituzionale Open Access dell'Università di Torino

\title{
Rituals and Routines: A Semiotic Inquiry
}

\section{This is a pre print version of the following article:}

Original Citation:

\section{Availability:}

This version is available http://hdl.handle.net/2318/91958

since

Terms of use:

\section{Open Access}

Anyone can freely access the full text of works made available as "Open Access". Works made available under a Creative Commons license can be used according to the terms and conditions of said license. Use of all other works requires consent of the right holder (author or publisher) if not exempted from copyright protection by the applicable law. 


\title{
Rituals and Routines: A Semiotic Inquiry ${ }^{1}$
}

\author{
Massimo Leone \\ University of Torino, Italy
}

\begin{abstract}
The article proposes a semiotic comparison between the phenomenological structure of rituals and routines, and claims that they share the same features of repetition through time, impossibility of change, unavailability of choice, and transcendental conception of origin. If a modern, structural conception of meaning based on alternative is adopted, both rituals and routines can be considered as meaningless. However, if the non-structural, pre-modern conception of meaning based on repetition is embraced, rituals and routines appear to be meaningful, although they do not have a meaning according to the structural semiotic ideology. The sense of belonging that emerges from rituals and routines (from routines as rituals) relies exactly on the feeling that no alternative is possible, that meaning depends on a subject's repetitive frequentation of a physical or conceptual space, and that dis-placement does not exist. The article concludes by focusing on the main phenomenological difference between a ritual and a routine - whereas the former is collective, the latter is individual —, contending that this is the main reason for which the existential value of rituals in pre-modern societies is not satisfactorily replaced by that of routines in contemporary societies. Routines offer to (post-)modern subjects an alienating feeling of belonging that fails to replace the sense of belonging guaranteed by pre-modern rituals. Only through rituals do subjects feel part of a collective routine that secures their feeling of belonging.
\end{abstract}

Keywords: Rituals; routines; belonging; semiotics

A lo mejor no es tan diferente, dijo Zulma que destendía la mesa, vos también tenés tus manías, el frasco de agua colonia a la izquierda y la gillete a la derecha, y yo no hablemos. Pero no eran manías, pensó Mariano, más bien una respuesta a la muerte y a la nada, fijar las cosas y los tiempos, establecer ritos y pasajes contra el desorden lleno de agujeros y de manchas $^{2}$.

Julio Cortázar, "Verano", Octaedro

\section{Phenomenological comparison between rituals and routines: similarities}

Firstly, the following question will be dealt with: what are the main similarities and the main differences between rituals and routines ${ }^{3}$ ? Such a comparison is possible because rituals

\footnotetext{
${ }^{1}$ A first version of this article was presented at the symposium "Metamorphoses of Rituals: From Archaic World toward Postmodern", Institute of Lithuanian Literature and Folklore, Vilnius, 17-18 April 2009. The article is part of a larger research project on the semiotics of belonging, which will hopefully give rise to a monograph in 2012.

2 "Perhaps it is not so different, Zulma said as she spread the tablecloth, you too have your manias, the bottle of cologne on the left and the razor on the right, not to speak about me. But they were not manias, Mariano thought, but an answer to death and nothingness, fixing things and times, establishing rites and passages against the disorder full of holes and stains" (trans. mine).

${ }^{3}$ The disciplinary field of ritual studies is very vast and fast developing. For an introduction, visit www.ritualstudies.com.
} 
and routines share at least some elements as regards their phenomenology. What are these elements?

The first similarity is an idea of repetition through time: in both rituals and routines, some elements of reality must be arranged in the exact, or almost exact, same combination. Such regularity of combination concerns time, space, actors, and acts: in the same space, at the same time, the same actors accomplish the same acts over and over again. From this point of view, the religious ritual of the Catholic procession of the Corpus Domini, for instance, is structurally similar to the routine of someone's morning shaving ${ }^{4}$. The procession implies that some actors (the priest, the assistants, the faithful, etc.) perform the same acts (prayers, liturgical gestures, movements, etc.) in the same space (the church, the parvis in front of it, the processional path, etc.) at the same time every year. Analogously, if morning shaving is a routine, it also implies its being performed with regularity at the same time (early in the morning), in the same space (in front of a specific mirror), with the same gestures, carefully repeated day after day with little or no variation (Hankiss, 2006).

The second shared element between rituals and routines stems from the first one: the idea of repetition through time and space gives rise to that of impossibility of change. In order for both rituals and routines to be such, no changes must be introduced in their development. The Monday after Easter, for instance, Italian Catholics usually have a picnic in the countryside, whose ritualistic nature would be spoiled if everybody picked a different weekday for its enactment. Analogously, someone's routine of placing a glass of water on the bedside table before going to bed would be disrupted should the glass be replaced by a bottle, or water by chamomile tea, or the bedside table by a chair.

Both rituals and routines must be repeated through time, and hence, neither admits any changes. These two elements bring about a third one: it would be strange to say that people "invent" rituals and routines; in general, people are said to "follow" rituals and routines. This expression reveals two ideas: first, neither rituals nor routines admit choices; second, they are not perceived as created by someone in a specific time and place.

The first aspect, i.e. the lack of choice, is evident both in religious rituals and in everyday routines. For instance, Catholic believers cannot choose to skip one of the stops of Christ's Passion, for that would deconstruct the ritual and transform it into a heretical performance. Analogously, as soon as one of the steps of a routine is not followed, the consequences are catastrophic: the routine ceases being such and turns into an isolated behavior. For example, one day someone chooses not to switch on the television in the evening and suddenly the whole structure and meaning of the evening is revolutionized.

As regards the second aspect, i.e. the lack of creation, if rituals have an origin, it is usually conceived of by their followers as transcendent (Tarasti, 2000), as situated out of the time and space of everyday life, where the sequence of words, gestures, movements, etc. that compose the ritual have not been shaped by a human hand, but instead, have been instituted by a god or a god-like ancestor. On the other hand, routines are not normally associated with a transcendent origin, but with an immanent one, this being one of the main differences between rituals and routines. However, despite this difference, followers of routines too often have the impression that they did not create the routines they follow, but that routines preexisted their acts, and it is exactly this feeling of pre-existence that enables them to follow them.

In English, as in many other languages, people are said "to have fallen into a routine", implying that routines pre-exist their followers and that they fall into them almost by

\footnotetext{
${ }^{4}$ The incipit of James Joyce's Ulysses plays with the similarity between Eucharistic ritual and morning shaving routine. For an in-depth phenomenological and semiotic analysis of religious processions, cfr Leone (Forthcoming A).
} 
accident, with no deliberate decision. For Catholics, for instance, the Eucharistic ritual was not created in a merely immanent hic et nunc but in the encounter between an immanent context and the transcendent initiative of Jesus. Similarly, the man who has the daily routine of going from home to his workplace by following a certain path, tends to forget that such a routine was created by him in a certain historical time or period even though there obviously must have existed an exact time or period when he started the routine. The routine took shape just as the time or period of its origin was somehow forgotten. Therefore, like rituals, routines are not thought of as something that people invent, but as something that people follow.

Repetition through time, change, choice, and origin are the similarities that give rise to the most important phenomenological element shared by rituals and routines: both are meaningless. Such a blunt statement requires a detailed explanation. Rituals and routines are meaningless if meaning is conceived according to structuralism: something emerging from difference, namely, from the choice between two different elements (Saussure, 1972). Given this conception of meaning, rituals and routines are meaningful only for those who analyze them from an external point of view (Pike, 1967). For the semiotician, for instance, all the elements composing the Catholic ritual of baptism or the daily routine of reading a newspaper are in opposition to other elements that could have been chosen in their place. Why is water used in baptisms instead of oil, and why are newspapers read in the morning rather than at night? Answering these questions is tantamount to determining the matrix of structural oppositions from which the meaning of both rituals and routines stems.

However, those who hold an internal point of view on rituals and routines do not experience them as something involving any opposition, but as predetermined structures where, as pointed out earlier, every possibility of change and choice is excluded. Water is not a matter of choice for the priest who baptizes a child, just as reading the newspaper in the morning does not admit any change for those who follow this routine.

As a consequence, if meaning is conceived according to structuralism, both rituals and routines are meaningless for those who follow them. Rituals and routines are rather experienced as a sort of second nature (McDowell, 1994): trying to understand their meaning as stemming from the opposition between alternative elements would be tantamount to trying to understand the meaning of breathing as stemming from the opposition between breathing and not breathing.

However, stating that rituals and routines are meaningless seems to contradict the common sense of followers. If meaning is value, both rituals and routines can hardly be defined as deprived of meaning, and therefore of value, for those who follow them. Both rituals and routines, instead, are so intensely valued by their followers that many of them feel that their lives would be meaningless without those rituals and routines.

Hence, if rituals and routines are meaningless according to the structuralist conception of meaning, and if this judgment of meaninglessness seems to strongly contradict the common sense of followers, it must be concluded that the structuralist conception of meaning is inadequate in grasping the way in which followers of rituals and routines experience them (Keane, 2003).

Such inadequacy arises from the fact that structuralism generally conceives of meaning as something that things have — a poem has meaning, a painting has meaning, a conversation has meaning, etc. - where the fact of being meaningful strictly depends on the opposition between the poem, the painting, and the conversation with other poems, paintings, and conversations that are meaningless or have a different meaning. However, from an internal point of view, rituals and routines do not have meaning. They cannot be opposed to other rituals and routines that have no meaning or have a different meaning. Their meaningfulness derives not from difference (what they are in relation to what they might 
have been) but from indifference, from their being considered as bound to be repeated without change and without choice over and over again.

This is why semiotics and other disciplines stemmed from structuralism can grasp the meaning of rituals and routines from an external point of view: as things that extrinsically have meaning, but not from an internal point of view: as things that intrinsically are meaning. Rituals and routines, indeed, challenge the basic postulate of structuralism, according to which meaning is based on difference, and therefore on the possibility of choice between two or more different alternatives. For structuralism, something has value because it has been chosen instead of something else. Without the possibility of this something else, nothing would have value, and therefore, nothing would have meaning. However, rituals and routines have value for their followers exactly because they are conceived of without alternatives, as being the only possible ritual, the only possible routine.

Structuralism's failure in understanding the meaning of rituals and routines as it is experienced by their followers reveals that the structuralist conception of meaning is not universal, as structuralists and semioticians have long claimed, but rather based on a specific semiotic ideology (Leone, 2010a; Forthcoming B), on a specific, historically, and culturally conditioned way of imagining meaning. Such imagination is based on the idea of alternative: something has meaning because it might have been different from what it is. However, such an idea is a relatively recent one, increasingly dominating "western" cultures in the last centuries. Whereas in many cultural areas, as late as the seventeenth century, one was obliged to follow the profession of one's father without any possible alternative (for profession was considered like second nature, handed down from generation to generation in a sort of ritual or routine), in the following centuries more and more aspects of one's life have been considered as a matter of choice between different alternatives. This development regards not only professions but also aspects of life that used to be considered such that no freedom of choice between different alternatives could be exerted on them: the shape of one's body, one's sexual orientation, the moment of one's death were not a matter of decision as they are nowadays in many "western" societies but were thought of as given by nature, or by God through nature, and as such, it was understood that they could not be changed (Leone, 2010b).

Nevertheless, one should not conclude that these aspects of life were meaningless in the pre-modern era. They were meaningful but according to a different, pre-modern conception of meaning. In pre-modernity, meaning was something that things were, and not something that things had, something that was because it could not be different from what it was, and not something that was had because something different might have been had instead.

Since semiotics - whose origins predate modernity but whose most important developments took place in the twentieth century - conceives of meaning according to the modern idea of alternative, it is hardly able to understand phenomena such as rituals and routines, which embody a different conception of meaning.

The main hypothesis of this article is that rituals and routines embody an idea of meaning as based on repetition, impossibility of change and choice, and naturalness of acts. This is opposed to the idea of meaning as based on innovation, possibility of change and choice, and cultural nature of acts. The first idea prevailed in the period of "western" history that is defined as "pre-modern", whereas the second is predominant in the period of "western" history that is defined as "modern". Nevertheless, from the point of view of the present section, "modern" and "pre-modern" are ambiguous labels. They give the impression that, since rituals and routines embody a "pre-modern" conception of meaning, a natural historical development going from pre-modernity to modernity will replace them with phenomena embodying a "modern" conception of meaning. According to this impression, pre-modernity as defined in relation to modernity - as something that comes before 
modernity - is therefore inevitably depicted as the natural outcome of the human struggle throughout history.

No conclusion could be more wrong. The labels "modern" and "pre-modern", if they have to be of some use, must not be considered as referring to historical periods but to anthropological or even biological ways in which human beings conceive of value and meaning as based on the ideas of repetition versus alternative. These ways mostly coexist throughout history but in different combinations: in some historical periods and socio-cultural contexts a conception of meaning as based on the idea of repetition is prevalent, while in other periods and contexts an opposite conception of meaning as based on the idea of alternative is predominant. Considering these labels as anthropological rather than historical allows one to understand the way in which a conception of meaning as based on repetition might return to be predominant and therefore be a characteristic not only of pre-modernity but also of post-modernity.

This is not an accident but depends on the intrinsic nature of human beings as a biological species: human beings require alternatives as they require repetition, and, in fact, human history shows that none of these two opposite conceptions of meaning has ever been able to entirely expel the other from the human scene (Leone, 2010c).

\section{Phenomenological comparison between rituals and routines: differences}

Thus far, most of the present article has been devoted to demonstrating the following point: highlighting similarities between rituals and routines and showing that both suit the human need for a conception of meaning as based on repetition, lack of alternative, and an ontology where something is meaningful exactly because it is what it is and not because it might be different.

The next part of the article will be devoted to pinpointing differences between rituals and routines, which may all come down to the opposition between individuality and collectivity. There is no such a thing as an individual ritual as there is no such a thing as an individual language. One can perform a ritual alone, as one can speak to oneself, yet in both cases the grammar of the ritual has been shaped by a collectivity, given that one of the main purposes of the ritual is to enable a collective experience of meaning as repetition.

On the contrary, there is no such a thing as a collective routine. Routines are experienced by individuals and as soon as they involve more than one person, they start to resemble more rituals than routines. One could even conclude that routines are an individualization of rituals just as rituals are a collectivization of routines.

Observing the way in which people live in contemporary "western" cities, it could be claimed that meaning is generally experienced more as based on alternatives than on repetitions. For instance, while in the past people mostly lived where they had been born and where their parents had been born, choosing the place where to live among numerous alternatives has increasingly become a common trend. In fact, conversation among young people in Europe and elsewhere frequently revolves around "the coolest city where to live". Similarly, young people consider themselves free to choose the area of a city where to live, the house to rent or buy, the work to do, the ways of moving across the city and out of it, the people to meet, the cafés, restaurants, and other entertainment places to frequent, the events to attend, etc. Meaning is conceived of as being inextricably related to this freedom of choice among alternatives and no aspect of life without alternative is thought of as meaningful.

Yet, such a liquid urban society inevitably brings about the need to experience meaning as repetition, as based not on the freedom of choice among alternatives, but on the necessity of something that is what it is because it cannot be different. Nevertheless, in most contemporary "western" cities, this need is satisfied not through rituals but through routines: 
people cross the city to move from house to work always in the same way, they always eat in the same cafés or restaurants, hardly ever go out of a certain area, always frequent the same cinemas, go grocery-shopping in the same supermarkets, moving around the shelves in the same way, buying the same products. No economic reason could explain such a tendency toward repetition in an economic environment where, on the contrary, citizens are constantly encouraged to try new alternatives of consumption. Indeed, such a tendency can be accounted for only if one takes into due consideration the human need for meaning as repetition.

However, there is something in the phenomenology of urban routines that makes them much less suitable to satisfy this need than rituals. Let us compare, for instance, an outdoor religious ritual as it might take place in a pre-modern Italian city with the daily routine of someone who walks through the city from house to workplace, following exactly the same path day after day. In both cases, meaning is experienced as repetition. In both cases, any small change in the path would disrupt the meaning of both the ritual and the routine. In both cases, the path is considered not as something that is invented or created, but as something that is followed almost naturally. In both cases, the meaning of the experience does not derive from having been freely chosen among different alternatives but from the absence of these alternatives, from the ineluctability of repetition. In both cases, the painful feeling of the flow of life toward death is somehow stopped through the illusion of a circular temporality, of an experience whose meaning consists in not admitting any changes.

And yet, there is a difference between the person who follows a procession and the person who follows a routine: while the former experiences meaning as timeless repetition together with a whole collectivity, the latter experiences repetition as solitude, at times coming across other solitary routines.

One of the most important metamorphoses of rituals in contemporary "western" urban contexts consists in the transition from the collective experience of repetition to the solitary experience of it, a transition from pre-modern urban rituals to modern urban routines that entails a series of consequences in the way in which contemporary cities are able to quench the human thirst for meaningfulness. Reviving traditional outdoor religious rituals will not be a solution. The solitude of routines will haunt citizens for a long time, until new forms of urban rituals are created.

\section{Theoretical conclusion}

Given the tensive semiotics of belonging developed in Leone (Forthcoming C), both rituals and routines can be conceptualized as semantic paths and rhetoric strategies meant to decrease the feelings of intensity of transition and extension of distance that subjects attribute to the crossing of a frontier between an environment of belonging and one of non-belonging. From this point of view, both rituals and routines can be considered as semantic paths and rhetoric strategies of acclimation and tolerance. Whenever a certain spatial enunciation creates a patterned opposition between an environment of belonging and one of nonbelonging and, therefore, a frontier separating them, rituals and routines provide the illusion of a reunification of such patterned space and, as a consequence, smooth out the sense of the frontier and the transition between the environments divided by it. In other words, both rituals and routines are semantic paths (from the static point of view) and rhetoric strategies (from the dynamic point of view) of re-placement. They confirm the relation between a subject (be it an individual, in the case of routines, or a group, in the case of rituals) and a space (be it "real" or virtual, physical or conceptual).

Examples are countless: on the one hand, collective rituals mostly aim at confirming the existential placement of groups (as well as individuals thought of as members of groups) on the occasion of particularly "delicate" transitions: between non-existence and existence (for 
instance, rituals of birth, such as the Christian baptism); between existence and non-existence (for instance, funerary rituals, such as the Hindu sati); between ages of life (for instance, rituals of initiation, such as bar mitzvah in Judaism); between seasons (for instance, seasonal rituals, such as those related to the beginning of winter in Celtic religions), and so on and so forth.

On the other hand, solitary routines mostly aim at confirming the existential placement of individuals on the occasion of equally "delicate" transitions: between strangeness and familiarity (for instance, routines that individuals adopt to introduce themselves to strangers), between "being at home" and "being in the world" (for instance, routines that are followed at the moment of leaving one's house or returning to it), between wakefulness and sleep (for instance, routines that are adopted at the moment of falling asleep or waking up), and so on and so forth.

As has been claimed, both rituals and routines work as strategies of acclimation and tolerance because they manifest the meaning of belonging not as related to a subjective agency that chooses among various alternatives but as related to a lack of alternatives and therefore to an absence of agency (Leone, 2009). From this perspective, both rituals and routines consist in a sort of naturalization of meaning, in a de-culturalization of it. Whereas the emergence of patterns in space - and the consequent emergence of frontiers dividing environments of belonging and environments of non-belonging - reveal, mostly through various forms of dis-placement, the cultural nature of any feeling of belonging and, as a result, its fragility, the rhetoric of both rituals and routines, mostly by smoothing out any sentiment of alternative and opposition, reconfirm the illusion of the natural essence of culture. In other words, in both rituals and routines, subjects are freed from the burden of choosing their path of meaning and existence so that they can enjoy the peacefulness of a perfect sedentary belonging.

From the strictly narrative point of view, whereas the enunciation of a frontier in a patterned space consists in what semioticians call a "débrayage", the semantic effect of both rituals and routines consist in a virtual return to the stage that preceded such enunciation, which semioticians call "embrayage" (Greimas \& Courtès, 1993; Leone, 2010d). The main narrative mechanism through which both rituals and routines perform such return to the feeling of an undivided space is the same through which fairytales help children "domesticate" the transition between light and darkness, day and night, being awake and being asleep, being with one's parents and being alone, etc.: repetition. Indeed, fairy tales do not work as rhetoric strategies of acclimation and tolerance so much because of their content but because of the repetition of it, the content being re-proposed night after night more or less with the same words (children would immediately complain if a change of words, or worse, plot occurred accidentally).

Whereas post-modern adults have learned to enjoy the feeling of non-belonging that emerges from the variety of meaning displayed by new stories, children (and pre-modern adults) are still attached to the feeling of belonging that emerges from the monotony of meaning manifested by old stories. And how comfortable is it, for adults too, to reread a book! What existential confirmation usually derives from it!

Nevertheless, one should also say that, after all, every story is nothing but the enactment of the restoration of a feeling of belonging after its fictitious disruption (Greimas, 1970; 1975, 1983). Stories would therefore be routines of meaning masked as variations of it. But this is not the point here. The point is to underline that in both rituals and routines, a feeling of sedentary belonging is produced though the same narrative structure that underlies traditional story-telling. It might be labeled "the zigzag structure". Very abstractly, such structure can be described as follows: at an instant $\mathrm{T} 1$, a subject $\mathrm{S}$ is in possession of an object $\mathrm{O}$. At an 
instant T2, the same subject is dispossessed of the object $\mathrm{O}$. At an instant T3, the subject $\mathrm{S}$ reappropriates the object $\mathrm{O}$, and so on and so forth.

The description of such structure might be further complicated, for instance, by introducing the difference between a static subject (which alternately loses and regains possession of an object), a static anti-subject (which gains the object when the subject loses it, and vice versa), a pragmatic subject (which acts in such a way to determine the conjunction or the disjunction between the static subject and the object) and a pragmatic antisubject (which is the abstract narrative counterpart of the pragmatic subject). However, what matters here is not so much the somewhat Byzantine subtleties of semiotics as the idea that, in rituals and routines, the relation of conjunction between a subject and an object of value, that is, between a subject and a space of belonging, is confirmed through this rhetoric rhythm in which such conjunction is temporarily disrupted only to be subsequently reestablished.

As Leone (2011; Forthcoming D) points it out, the purpose of post-modern travelling, for instance, is often analogous to that of storytelling: it is a routine that simulates the creation of a frontier separating the traveler from her environment of belonging, but merely in order to grant the traveler the existential pleasure of return, the pleasure that emanates from the elimination of such temporary frontier. This is exactly why the existential experience of frontiers in traveling and exile are so different.

Given the conceptualization of both rituals and routines as narrative rhythms that succeed in creating the illusion of the continuity of an environment of belonging, the difference between the former and the latter can be redefined in terms of symbolic efficacy. To put it in simple words, rituals are generally more effective than routines because they add the pragmatic effect that stems from synchronization to the pragmatic effect of narrative rhythm. Whereas in routines the narrative rhythm of conjunction / disjunction / reconjunction is followed by an individual subject, in rituals the same rhythm is adopted by a multiplicity of individual subjects merging into the same collective agent, sharing the same collective agency.

The creation of collective agencies often takes place through logics of contagion (Manetti et al., 2003; Landowski, 2004): individual subjects affected by the narrative rhythm adopted by other subjects start following it, thus increasing the agency of collective subjects and simultaneously augmenting its power of attraction. Until more or less a decade ago, for instance, the festivity of Halloween was not celebrated in Italy. Instead, on October 31, people would prepare for the celebration of the Catholic festivity of All Saints and for the Commemoration of the Dead. From a general cultural point of view as well as from the more specific perspective of the phenomenology and semiotics of belonging, it might even be argued that the festivity of Halloween and that of the Commemoration of the Dead are contradictory rituals: whereas the former enacts an "invasion" of the dead beyond the frontier that separate their environment of belonging from that of the living, the (at least Catholic) Commemoration of the Dead is often construed as an opposite movement: the living spontaneously choose to "visit" the dead and the environment of non-existence and memory to which they belong (Santino, 1994; Markale, 2000; Skal, 2002).

Nevertheless, at the turn of the millennium, in Italy too some individual subjects particularly exposed to US customs started celebrating Halloween as well as All Saints and the Commemoration of the Dead (Foley \& O'Donnell, 2009). The new festivity entailed a playful dimension that was particularly attractive to children and, as a result, to the market. In the following years, the marketing of Halloween became increasingly intense and gained a growing number of adepts, to the extent that many (including the Catholic Church) currently fear that this new festivity threatens to supersede those of All Saints and the Commemoration of the Dead. 
This is how a new ritual is born: given a frontier between an environment of belonging and that of non-belonging (in the case mentioned above, the frontier between the "world of the living" and the "world of the dead"), and given a ritual A that domesticates the transition across such frontier, an increasing number of individual subjects choose to follow an alternative ritual $\mathrm{B}$ that, at least to them, proves to be more effective in bringing about a semantic path and rhetoric strategy of acclimation and tolerance, in creating a feeling of sedentary belonging. However, the more individual subjects choose such alternative ritual and its narrative rhythm, the more its symbolic efficacy is able to affect other individual subjects, who are therefore also pushed to relinquish the old ritual and embrace the new one.

But why do individual subjects give up old narrative rhythms only because they become unpopular, and why do they embrace new narrative rhythms because of their popularity? Because when collective rituals become too unpopular, they run the risk of turning into individual routines and, vice versa, when individual routines become very popular, they begin looking like collective routines.

In other words, for the narrative rhythm conjunction / (fictitious) disjunction / reconjunction to work as a rhetoric strategy of acclimation and tolerance, it has to be followed by a multitude of individual subjects merging into a collective one, sharing the same agency. The more individual subjects follow a particular narrative rhythm, the more such a rhythm will turn out as symbolically efficacious, thus encouraging other individual subjects to embrace it. Vice versa, the more individual subjects give up following a particular narrative rhythm, the less such a rhythm will turn out symbolically efficacious and hence push other individual subjects to relinquish it. Put very simply, rituals are socially successful routines, whereas routines are socially unsuccessfully rituals. But why do rituals lose the power to congregate individual agencies, thus turning into solitary routines, and why, on the contrary, do routines acquire the capacity to attract individual agencies and thus progressively become collective rituals? Through which semiotic processes do both rituals and routines gain and lose their symbolic efficacy? Further research will have to find suitable answers to these central questions.

\section{References}

Foley, M. \& O’Donnell, H. (eds.). (2009). Treat or Trick? Halloween in a Globalising World. Newcastle upon Tyne: Cambridge Scholars Pub.

Greimas, A. J. (1970). Du sens. Paris: Seuil.

Greimas, A. J. (1975). Maupassant: la sémiotique du texte, exercices pratiques. Paris: Seuil.

Greimas, A. J. (1983). Du sens II. Essais sémiotiques. Paris: Seuil.

Greimas, A. J. \& Courtés, J. (1993). Sémiotique: Dictionnaire raisonné de la théorie du langage (1979). Paris: Hachette.

Hankiss, E. (2006). The toothpaste of immortality: Self-construction in the consumer age. Washington, D.C.: Woodrow Wilson Center Press; Baltimore, Md.: Johns Hopkins University Press.

Keane, W. (2003). Semiotics and the social analysis of material things. Language \& Communication, 23, 409-425.

Landowski, E. (2004). Passions sans nom: Essais de socio-sémiotique 3. Paris: PUF.

Leone, M. (ed.). (2009). Attanti, attori, agenti: Il senso dell'azione e l'azione del senso: Dalle teorie ai territori / Actants, actors, agents: The meaning of action and the action of meaning: From theories to territories. Monographic issue of Lexia, new series, 3-4, December.

Leone, M. (2010a). Semiotic ideology and its metamorphoses. In D. Teters (ed.), Metamorphoses of the world: Traces, shadows, reflections, echoes, and metaphors, 2010, 133-146. Riga: Riga Technical University. 
Leone, M. (2010b). Pudibondi e spudorati: Riflessioni semiotiche sul linguaggio del corpo (s)vestito. Rivista Italiana di Filosofia del Linguaggio, 2, 74-94.

Leone, M. (2010c). Legal controversies about the establishment of new places of worship in multicultural cities: a semiogeographic analysis. In A. Wagner \& J. Broekman (eds.), Prospects in Legal Semiotics. Berlin and New York: Springer, 2010, 217-237.

Leone, M. (2010d). Le Repentir: Une énonciation fragmentaire. Nouveaux Actes Sémiotiques. Retrieved December 31, 2010, from http://revues.unilim.fr/nas/document.php?id=3613.

Leone, M. (2011). Dal panorama alla prosopopea: Appunti per una semiotica del corpo viaggiante. In G. Proni \& D. Gasperi (eds.), Alibi: Verso una semiotica del viaggio. Monographic issue of Ocula. Retrieved January, 2011, from www.ocula.it.

Leone, M. (Forthcoming A). Transcendence and transgression in religious processions. In P. Forsell \& R. Littlefield (eds), Transcending signs: Essays around Eero Tarasti's existential semiotics (Forthcoming). Berlin \& New York: Mouton de Gruyter.

Leone, M. (Forthcoming B). Dall'ideologia linguistica all'ideologia semiotica - Sulla smentita, submitted for publication in M. Sbisà, S. Carlomagno, \& P. Labinaz (eds.). (Forthcoming). Proceedings from the $17^{\text {th }}$ Congress of the Italian Society for the Philosophy of Language, Trieste 16-18 September 2010, special issue of Esercizi filosofici.

Leone, M. (Forthcoming C). Introduction to a semiotics of belonging. Submitted to Semiotica.

Leone, M. (Forthcoming D). On the semiotics of begging. Submitted to Social Semiotics.

Manetti, G. et al. (eds). (2003). Il contagio e i suoi simboli - Saggi semiotici. Pisa: ETS.

Markale, J. (2000). Halloween: Histoire et traditions. Paris: Imago.

McDowell, J. H. (1994). Mind and world. Cambridge, Mass.: Harvard University Press.

Pike, K. L. (ed.). (1967). Language in relation to a unified theory of structure of human behavior ( $2^{\text {nd }}$ edition). The Hague: Mouton.

Santino, J. (ed.). (1994). Halloween and Other Festivals of Death and Life. Knoxville: University of Tennessee Press.

Saussure, F. (1972). Cours de linguistique générale. T. de Mauro, (ed.). Paris: Payot.

Skal, D. J. (2002). Death Makes a Holiday: A Cultural History of Halloween. New York, N.Y.: Bloomsbury.

Tarasti, E. (2000). Existential semiotics. Bloomington, IN: Indiana University Press. 